\title{
WORDS AND MUSIC: ORAL AND LITERARY
}

\author{
Joseph C. Allard
}

Most scholarly and critical work concerning medieval Icelandic literature over the past one hundred and fifty years has assumed that the eleventh and twelfth centuries witnessed a shift in the practice and mode of learning in Iceland from an oral tradition, what Walter Ong terms 'primary orality' (Ong 1982: 13), to a mainly literate and literary one. The argument goes that with the invention and development of a method of writing Old Norse/Icelandic after the advent of Christianity, Icelanders with the new technology gradually became the dominant voice in a culture that previously had been almost purely oral, runic inscription being the exception. My contention in this essay is that the oral and literary traditions at their extremes are different in kind: the oral being essentially a performance art, the literary a text specific one. Away from the extremes, however, there is a regular and fruitful interface between the oral and the literary that should always be borne in mind when considering the origins of the literature that we have today.

During the years in question, and for a long time after, the oral and literary traditions happily co-existed. Since the seventeenth century the study of Old Icelandic literature and culture has focused upon the written, later printed, word. From the philological developments of the eighteenth and nineteenth centuries to the twentieth century 'bookprose' arguments of the Icelandic School, which consider the sagas to be authored texts, most of our approaches to the past have been governed by the written record and our interpretations of it. The proponents of the so-called 'freeprose' theories, who maintain that the sagas as we have them are the result of the inscriptions of oral traditions, were fighting a losing battle in the last century. The 'bookprose' theorists don't deny the vigour and importance of an oral tradition but, since their business is about words on the page, they find it difficult to say very much about orality in practice. I believe that to approach the creation of the literature as either/or, 'freeprose'/'bookprose', misrepresents what actually happened, rather than clarifies anything. It has been too

http://www.folklore.ee/folklore/vol20/literary.pdf 
Words and Music: Oral and Literary

easy to imagine the oral tradition in Iceland to have been equivalent to what we know about ancient Mesopotamia or the pre-literate tribes in twentieth century Africa discussed by Jack Goody (Goody 1987). Although it is generally acknowledged that an oral tradition and writing can co-exist in the same society, ancient Egypt for example, it is thought that they remained exclusive. "The two existed side by side, not, of course, within the same group (Southern Slav) but certainly within the same district." (Lord 1060: 135, my emphasis)

I believe these traditional and, it seems, universally accepted attitudes are too extreme. The late eleventh, twelfth and thirteenth centuries in Iceland, and, indeed, many centuries after, saw the comfortable, and mutually nourishing, co-existence of several modes of composition, memory and inscription. The older oral traditions weren't displaced, replaced, or suppressed by newer literate and literary modes as we so often presume. They carried on in good health for centuries forming what has recently been called a 'shadowgrowth' of literature that has simply been ignored by scholars until very recently (see the recent work of Driscoll, Glauser, and Jón Karl Helgasson). We have tended in the past century and a half to view the history and development of Icelandic literature from an increasingly narrow, literate point of view. I hope to show here that a consideration of different kinds of musical inscription and performance in the last two hundred and fifty years reveals an analogous variety that can shed light on the years during which old Icelandic literature was composed, performed, read, listened to and inscribed.

In our various speculations about the origins and continuities of Icelandic literature we tend to forget that from the beginning and for many centuries thereafter it was largely a performance art whether oral or written. Almost all elements of poetic and narrative production were shared in the community during the kvöldvaka (literally 'evening-wake'), the evening entertainment on farms during the winter which began with the lighting of the oil lamp usually an hour after sunset. This was the arena for sagnaskemmtun (literally 'saga-diversion') when, according to Eggert Olafsson and Bjarni Pálsson in their 1772 Reise igiennem Island, the head of the household or a young boy or a guest read or related sagas or performed 
Joseph C. Allard

rimur, the metrical versions of these and other tales. The point of the exercise, according to Eggert, was to keep people entertained and alert as they performed their evening chores (spinning and carding wool, knitting and so forth) (Driscoll 1997). Such performances were not unidirectional - reader or teller to the audience - but were participatory. The audience wasn't passive. According to the Scots bible promoter Ebenezer Henderson, who spent the winter of 181415 in Iceland, "the reader is frequently interrupted, either by the head, or by some of the more intelligent members of the family, who make remarks on various parts of the story, and propose questions, with a view to exercise the ingenuity of the children and servants." Eiríkur Magnússon notes in an unpublished Cambridge lecture "the interest taken in these readings is very remarkable. The handmaidens, as well as everybody else [,] make their laconic remarks as the story develops on the character of this or that hero, and on the tragic as well as the comic interest of the whole situation. The intelligence, yea even acuteness of the art[ist]ic perception which manifests itself in the remarks of the women is often very striking." As I will argue in due course, this kind of performance atmosphere has more in common with audience and performers in a jazz performance than with either the much more formal and one-directional nature of the classical music performance, which is so firmly rooted in a prescriptive notational tradition, or with the experience of reading in silence to oneself.

The last century has been a period of communicative multiplicity we have been living for a long time with the coexistence of a literary tradition and more recent ones concerned with the visual and aural image (Radio/Cinema/TV/IT/DVD, etc.). This is what Ong terms 'secondary orality' (Ong 1982: 133). Further to illuminate the multiplicities I'm suggesting, it's worth recalling in some detail the distinctions Richard Perkins makes between the oral and the literary traditions:

A: 'primary oral tradition': transmission: orally, by sound waves; reception: aurally, by sound waves; storage; cerebrally, in human brains.

B: 'literary tradition': transmission: cerebrally, by temporary storage in the brain, and then manually or mechanically, by the writing of manuscripts and printing of books; reception: visually, by light 
Words and Music: Oral and Literary

waves reflected from manuscripts or printed pages and aurally when read aloud in company; storage: in manuscripts and printed books to be retrieved cerebrally and aurally by reading and listening. (Perkins 1989: 239-240).

C: 'secondary oral tradition': transmission: visually and aurally by light and sound waves from a variety of mechanical and electronic sources; reception: visually and aurally, by light waves broadcast from screens and sound waves from speakers; storage: electronically in computer memories (for IT) or as images on film (Cinema, TV) or sound recordings on wax, vinyl, tape or disk.

I think it significant that the human brain plays a much less significant role in secondary orality. Our 'memory' is now measured in gigabytes and stored in a box on the desk. These further complexities to Perkins' model in the electronically generated images (visual and aural) in the twentieth and twenty-first centuries, and the fact that our book-related pursuits have happily coexisted with, indeed have been shaped by secondary oral modes, suggest to me that it has been a mistake to over-prioritise the literate at the expense of the oral. This places us in a position better to appreciate what might really have happened during the medieval Icelandic years in question.

It seems to be a commonplace assumption in much of the scholarship of the last century that an older oral tradition of saga entertainment in which performers had to rely on their memories and narrative skills, was gradually replaced by saga reading. It is probably more correct to imagine that oral performances and readings would have coexisted for many years. Indeed, certain at least partly oral modes and practices like the rimur and other poetic forms had an unbroken continuity from the fourteenth into the early twentieth century. The rimur tradition was a written form but intended for oral (and aural) delivery and reception. There is an instability in the rimur texts that suggests in Driscoll's words that in "the process of copying, and presumably also in performance, copyists and kvæðamenn would not have felt themselves bound to reproduce in every detail the exemplars in front of them" (Driscoll 1997,1: 236). Elsewhere Driscoll records another telling anecdote: "Jónas Kristjánsson... has told me that as a child he was told sagas by his grandfather. Although he may sometimes have consulted written 
Joseph C. Allard

texts- in at least some cases the rímur rather than the prose texts beforehand in order to refresh his memory, no written texts were ever used in the actual telling. This kind of re-telling of sagas and saga episodes to children was probably not uncommon in the late nineteenth and early twentieth centuries" (Driscoll 1997,2: 199200).

Another common scholarly assumption is that many of these forms were either superseded by literacy and reading or were suppressed by the Church and ceased to exist. Quinn puts it like this: "At the other end of the spectrum of oral discourses are ethnic traditions that were deliberately suppressed by the Church. Needless to say, the textualization of these traditions is unlikely to have taken place, but we do know a little about some of them from the wording of their explicit suppression. Bishop Jón Ogmundarson (d.1121) forbade the reciting of love poems (mannsöngskvæði, mannsöngsvísur), an apparently popular tradition in which a man and a woman exchanged improvised verses" (Quinn 2000: 36). That Bishop Jón wanted to suppress a tradition doesn't necessarily mean that he was very successful. Icelandic literary history is packed with indignant clerics and intellectuals denouncing 'wicked and foul' or 'vulgar and common' modes of popular poetry. It is a list of notables including Guðbrandur Porláksson (c.1541-1627), Ludvig Harboe (in Iceland 1741-1746), Magnús Stephensen and Hannes Finnsson during the Enlightenment ("I have often suffered from the knowledge that on many farms troll stories and fairy tales filled with vulgarities and superstitions were read" 1796), Jónas Hallgrímsson in his article in Fjölnir in 1837 (the rímur destroy and spoil "all feeling for what is beautiful and poetic and worthy of good poetry"), representatives of the Romantic movement like Benedikt Gröndal (18261907) in his dismissive review in Pjóðólfur in 1852 of Fjórar Riddarasögur ("I know that people would be bored by lists of vulgarities, Danicisms, totally warped geographical descriptions, and the like; but should anyone desire to see that sort of thing, then let him read Fjórar Riddarasögur, and no-one would believe that such a thing could be published in 1852!"), (trans. Glauser 1994) and into the twentieth century. To be contentious and deadly serious about literary matters has always been a quality of Icelandic intellectual life. Consider, more recently, the parliamentary and legal furore in the 1940s concerning Ragnar Jónsson, Stefán Ögmundsson and 
Halldór Laxness's edition of Hrafnkatla with modernised spelling (which was outlawed by parliament: a decision later overturned by the Supreme Court), or the debate in the 1950s about whether the modernist 'Atom Poets' were writing poetry at all. The exchange of verses (usually sung) between men and women remains a fixture of any good Porrablót (although not, usually, improvised). There are, clearly, several dominantly oral modes that might form a part of the kvöldvaka that continued in daily practice for centuries. In a similar oral tradition as recently as 1935 the popular people's poet Hjálmar frá Hofi was challenged to a poetic duel ('heiðarlega hólmgönguáskorun') by his rival Sveinn Skáld frá Elivogum. "Orustan var hád 30. marz 1935 í Varðarhúsinu í Reykjavík fyrir fullu húsi af áheyrendum." (battle was joined on March 30th 1935 in Varðarhusið in Reykjavik in front of a full house of listeners). Although a number of poems by both Hjálmar and Sveinn were published in mid-century, the poems from the duel were, in their nature, oral and are not, as far as I'm aware, recorded (Hjálmar frá Hofi 1950).

In The Nature of Narrative Robert Kellogg uses both the Homeric poems and the Icelandic sagas as part of his discussion of oral composition. Formal characteristics include 'formulaic' diction - that is, the language is controlled by a traditional 'grammar' which provides a limited number of patterns selected from the total language of the culture by which metrically (in the case of poetry), syntactically, and semantically appropriate utterances are formed. Kellogg maintains that the 'saga style' evinces just such a 'grammar', which is the basis of the Icelandic achievement, and explains the highly stylised nature of the prose. Another characteristic of oral narrative is consistency in the thematic significance of motifs, topoi, and plots - conventional narrative elements that govern the story's representation and its illustration of ideas.

If I am right that the oral and newer literary traditions co-existed quite comfortably in twelfth century Iceland then we might expect that the surviving written texts from the period would be less fixed and specific, and might exhibit a greater variety of nuance and suggestion, than the writing from a later, more text dominated period. Our almost utter enslavement to the text post-dates printing and is, like so much in our learned culture, a symptom of certain lateeighteenth and nineteenth century developments that have had an 
Joseph C. Allard

exaggerated and distorting influence on thought, methodology and understanding since. The over-emphasised dominance of the (printed) text has led to the situation in which we find it very difficult to cope sensibly with the oral tradition. It is part of our intellectual tradition either to ignore or avoid the oral tradition or to treat oral texts that have been inscribed as if they were the same as texts authorially written. The differences between the two, however, are great. The written text is far more prescriptive, specific and, in a way, limited than its oral counterpart. As Foley puts it: "[the] written text is a more deterministic libretto, its unitary character providing enough (and precise enough) signals to marshal the reader's activity quite - or at least comparatively - strictly; variation in the experience of a written work is thus relatively closely controlled by the work itself. However the reader performs the written work, the text from which he creates the experience is fundamentally original and unique, the only one of itself." (Foley 1987: 198) In the oral tradition the variety of performance prototypes would be neither so strictly controlled nor so singular in specificity - that is, there is a larger number of types of sagas and stories than we normally acknowledge.

I would like to suggest a further analogy that sheds light on the differences in question. That is a comparison of musical performance (and inscription) in the classical tradition and the jazz performance. The classical performance is in the literate tradition. At the start of the process the performer 'reads' the text. Since the late eighteenth century the text dictates an increasing multiplicty of directions: in addition to key and time signatures and the pattern and duration of notes and rests in harmonic space (which are essential for any musical notation) there are directions for tempo, phrasing, dynamics, mood, and so on. A text for piano by Schumann will have twenty-eight or more directional indicators (see appendix). The performance, thus, is a representation of an original and unique text strictly determined by the composer. In the performance, which is not unlike a religious ritual, a passive audience sits in rapt silence to watch and listen to the recreation of a somehow 'sacred' text by an inspired player. The performance is judged, partly if not largely, upon fidelity to an original text. Pushed to extremes this can lead to the idea of the 'perfect' performance that is an 'exact' representation of an original. 
Jazz, on the other hand, is centrally improvisational and communal. Usually there is a basic idea (a traditional song or tune) and certain formulaic grammars and structures (12 bar blues, for example) but the end of a jazz performance is an ever new interpretation of, or play with, these basic motifs. No two jazz performances will be alike. To inscribe, to write down, a particular performance is to fix it, certainly, and to preserve it for future improvisation, but, in itself, the inscription is a pretty artificial exercise. But any real jazz performance, whether based on an inscription or not, will be unique and different from all others. The ideal jazz gig is a collection of players who join the evolving musical process when they have something to say. As in the oral prose tradition there is a grammar (modal and harmonic structures), there are traditional motifs, a 'formulaic diction' if you will. But there is always a good deal of freedom. The arrangement of the Thelonius Monk number (see appendix) has almost a third of the directional symbols as the Schumann: as few as eleven.

This distinction between the classical 'written and read' tradition and jazz improvisational tradition has more than simply analogic or metaphoric significance to our concerns with the oral as opposed to the written narrative traditions. In music, as in literary studies, it is during the late-eighteenth and nineteenth centuries that the text achieves such complexity and dominance. Earlier composers and performers were given less direction and, one imagines, expected to be more improvisational. The text of the Bach 'Ricercar' (see appendix) sent to Fredrick the Great as part of his Musikalisches Opfer ('Musical Offering') in 1747 is closer to Monk than to Schumann: here there are as few as nine commands. Performers would be expected to play with it, rather than simply reproduce it. In fact the 'Ricercar' is Bach's own later inscription of his improvisation on the theme during his visit to Fredrick's court at Potsdam in 1744 .

We can better understand the way the jazz tradition functions if we consider the recording of two performances by the Modern Jazz Quartet in the 1950s. 'Softly, as in a Morning Sunrise' (from Oscar Hammerstein and Sigmund Romberg's New Moon) was a regular part of their performance repertoire. ${ }^{1}$ In the April 1952 recording with Milt Jackson (vibes), John Lewis (piano), Percy Heath (bass) 
Joseph C. Allard

and Kenny Clarke (drums) the performance lasts for three minutes and twenty-five seconds. On their album 'Concorde', recorded in July 1955, with Connie Kay on drums, the performance lasts for seven minutes and fifty-seven seconds. The differences are instructive. The second is still based on the Hammerstein/Romberg idea but it is now started and concluded with a play with 'Canon V' from Bach's Musikalisches Opfer (see appendix) from 1747. The Bach makes perfect musical sense in the context. Each time the MJQ performed 'Softly, as in a Morning Sunrise', or indeed any other number, they performed it differently - a prime example both of freedom of improvisation and of textual instability - indeed, a near absence of text altogether.

Roger Scruton makes an interesting observation in this context: "The jazz performer is, in a sense, also the composer, or one part of a corporate composer. But to describe free improvisation in that way is to assume that composition is the paradigm case, and improvisation secondary. It would be truer to the history of music, and truer to our deeper musical instincts, to see things the other way round: to see composition as born from the writing-down of music, and from the subsequent transformation of the scribe from recorder to creator of the thing he writes. Jacques Derrida has famously criticised Western civilisation as 'logocentric' - privileging speech over writing, as the purveyor of human intention. The criticism is the opposite of the truth: writing has been so privileged by our civilisation, in religion, law, and politics, as well as in art and literature, that we tend to lose sight of the fact that written signs owe their life to the thing which is written down" (Scruton 1997: 439).

Written texts are more prescriptive and determined than their oral counterparts, which depend much more on the freedom of performance. If I'm right then we should be able to discern some qualities in the saga style that incline towards the performance [the often noted paratactic style, terseness, laconism, few adjectives, little or no qualitative commentary from the saga inscriber]. Imagined back into the kvöldvaka situation during which, as we know, the listeners might often interrupt, and members of the household might have their thoughts and feeling solicited, the performance situation becomes much clearer - the function of the 'text' as it has been transmitted to us, becomes more transparent and, perhaps, potentially even more unstable. 
Words and Music: Oral and Literary

\section{APPENDIX}

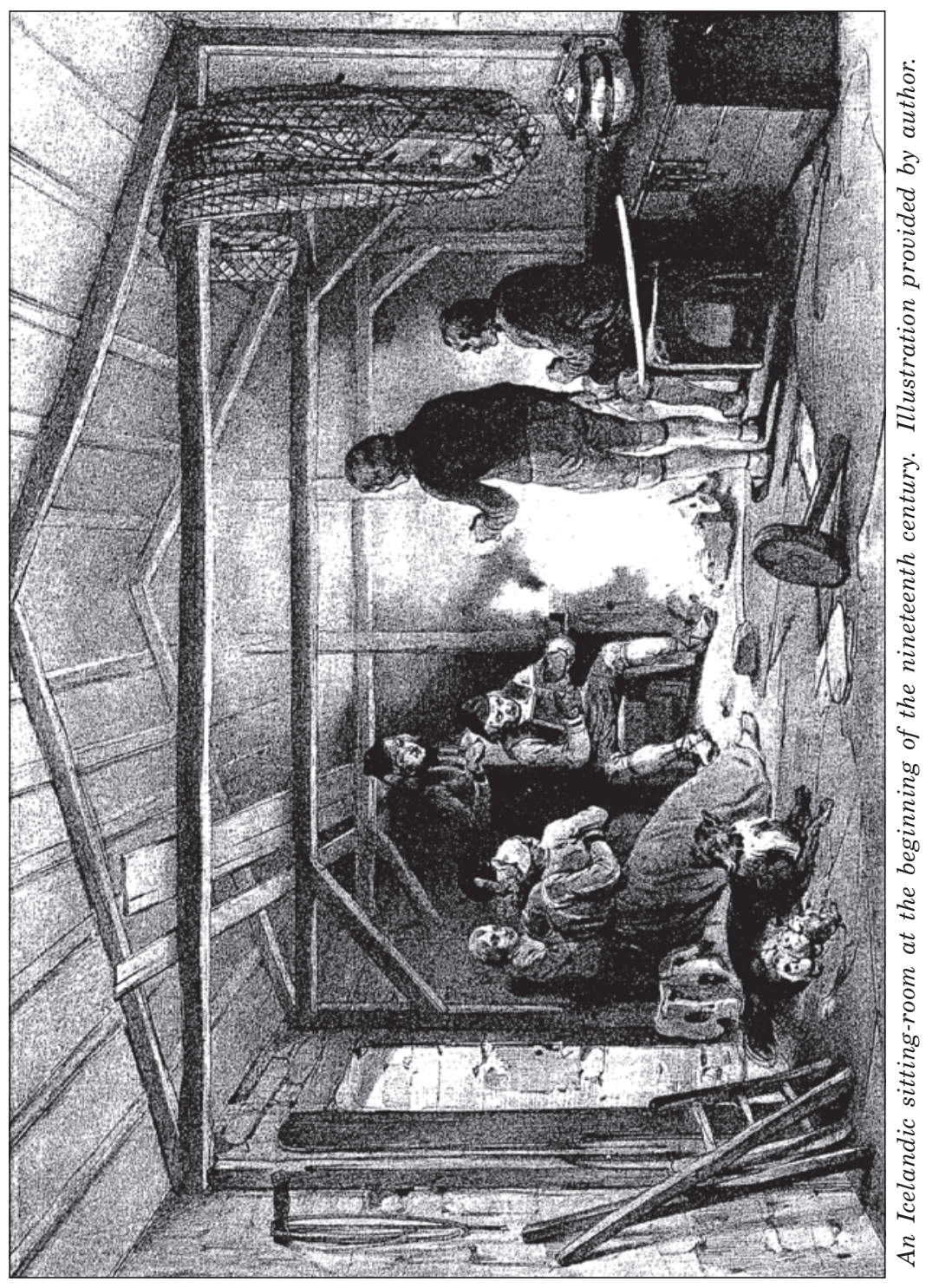




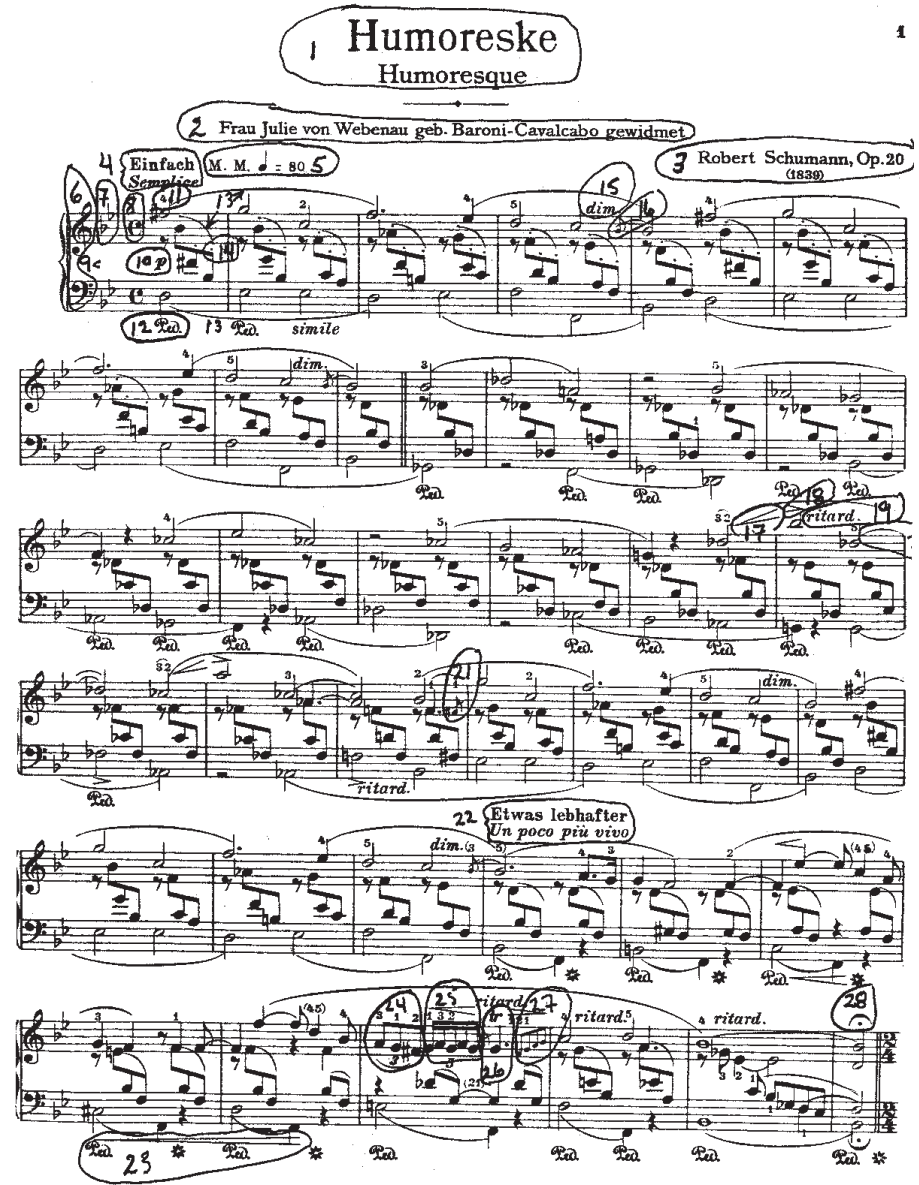

Robert Schumann 'Humoreske' Op.20, 1839.
1. title
11. fingering
2. dedication
12. pedal point
19. tempo suggestion
3. opus num
13. slur/phrasing mark
mber and date
14. staccato
(bilingual)
15. a dynamic suggestion
5. metronome marking
(dim.)
6. clefs
16. a
lean)
key signature
17. crescendo
a to
8. time signature
18. accent/attack
(retard.)
20. tie
21. grace note
22. tempo/mood change
23. bass crescendo
24. triplet
25. quintuplet
26. trill
27. grace series
28. pause 


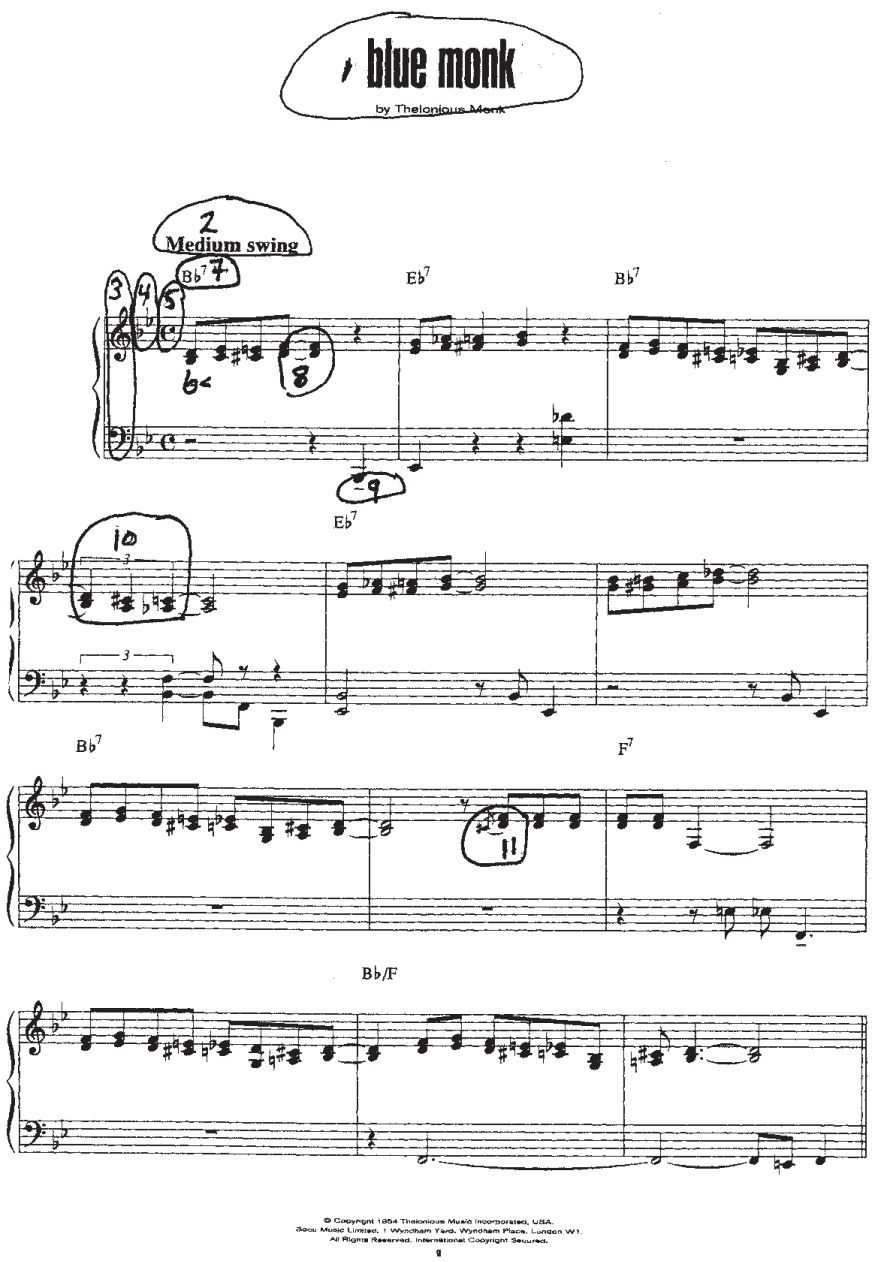

Thelonious Monk 'Blue Monk', 1954; arranged by Steve Hill ('to reflect Monk's own individual, timeless style'), 1993.

1. title

2. $\operatorname{mood}$

3. clefs

4. key signature

5. time signature

6 . note and rest symbols

7. harmonies

8. tie

9. agogic accent

10. triplet

11. grace note 
Joseph C. Allard

Regis Iussu Cantio Et Reliqua Canonica Arte Resoluta.
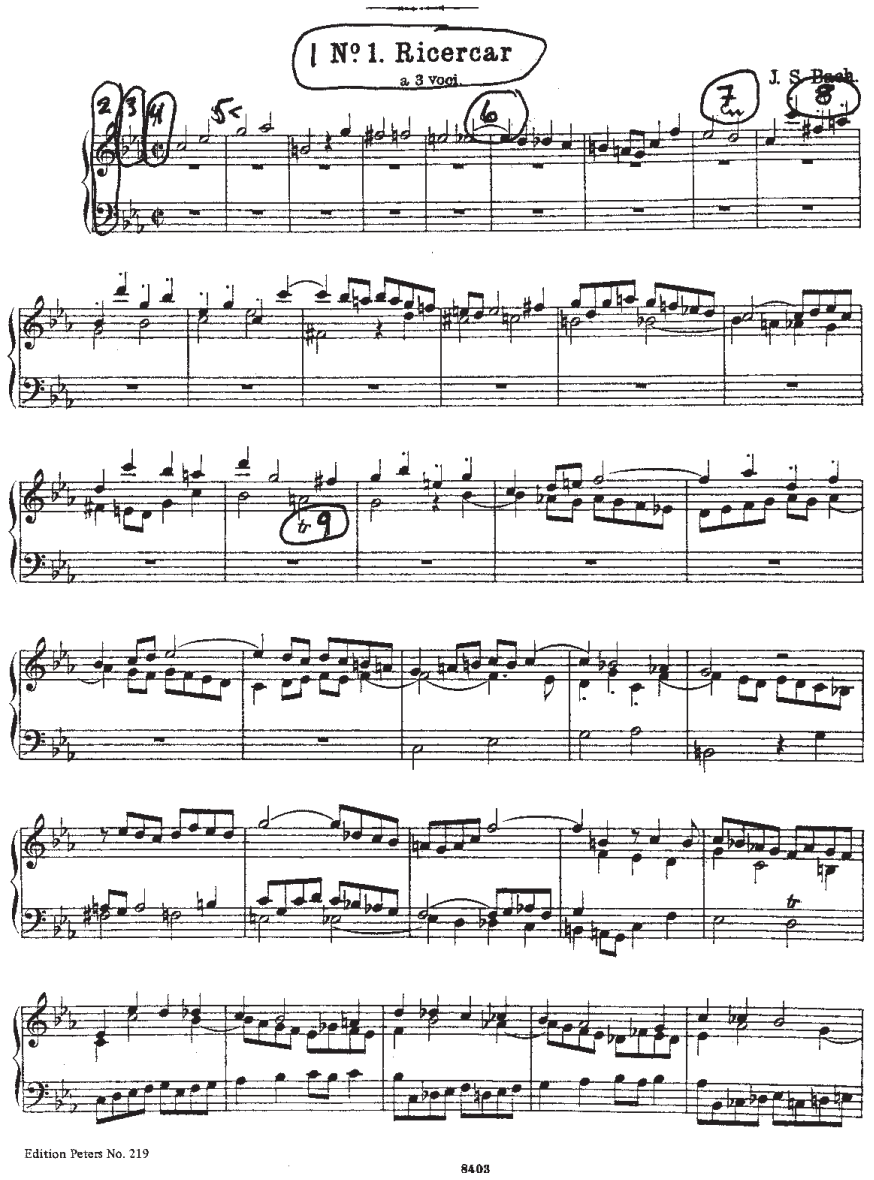

J. S. Bach 'Ricercar’ from Musikalisches Opfer, 1747.

1. title

2. clefs

3. key signature

4. time signature

5. note and rest symbols

6. tie

7. mordent

8. staccato

9. trill 
Words and Music: Oral and Literary

\section{Comments}

${ }^{1}$ A sample of the following two recordings can be found on the following addresses. Please note, that the samples are $4 \mathrm{MB}$ and $9 \mathrm{MB}$, respectively.

http://www.folklore.ee/folklore/vol20/allrd01.mp3

http://www.folklore.ee/folklore/vol20/allrd02.mp3

\section{References}

Allard, Joe 1998. Homer, Aristotle and the Sagas of the Icelanders. Scandinavian-Canadian Studies 11, pp. 15-33.

Andersson, Theodore M. 1964. The Problem of Icelandic Saga Origins. New Haven \& London: Yale University Press.

Bach, J. S. 1747 Musikalisches Opfer, Leipzig 1774.

The Complete Sagas of Icelanders, Viðar Hreinsson (ed.) 1997, Reykjavík: Leifur Eiríksson Publishing.

Driscoll, Matthew J. 1990. Pögnin mikla. Gísli Sigurðsson, Gunnar Harðarson \& Örnólfur Thorsson (eds.). Skáldskaparmál I, Reykjavík: Stafaholt hf, pp. 157-168.

Driscoll, Matthew J. 1997a. Words, Words, Words: Textual variation in Skikkjurímur. Gísli Sigurðsson,Gunnar Harðarson \& Örnólfur Thorsson (eds). Skáldskaparmál 4, Reykjavík: Stafaholt hf. Pp. 227-237.

Driscoll, Matthew J. 1997b. The Oral, the Written, and the In-Between: Textual Instability in the Post-Reformation Lygisaga. Tristram, Hildegard L. C. (ed.). Medieval Insular Literature between the Oral and the Written II. Tübingen: Gunter Narr Verlag, pp. 193-220.

Foley, James Miles 1985. Reading the Oral Traditional Text: Aesthetics of Creation and Response. Foley, John Miles (ed.). Comparative Research on Oral Traditions: A Memorial for Milman Parry. Columbus, Ohio: Slavika Publishers, 1987, pp. 185-212.

Foote, Peter 1953-1957. Sagnaskemtan:Reykjahólar 1119. Saga-Book. London: Viking Society for Northern Research, pp. 226-239.

Glauser, Jürg 1994. The End of the Saga: Text, Tradition and Transmission in Nineteenth- and Early Twentieth-Century Iceland. Wawn, Andrew (ed.). Northern Antiquity: The Post-Medieval Reception of Edda and Saga. Enfield Lock: Hisarlik Press.

Goody, Jack 1987. The Interface Between the Written and the Oral. Cambridge: Cambridge University Press.

Henderson, Ebenezer 1819. Iceland; or the Journal of a residence in that Island, during the Years 1814 and 1815. Phenomena, History, Literature, and Antiquities of the Island; and the Religion, Character, 
Joseph C. Allard

Manners, and Customs of Its Inhabitants. With an Introduction and Appendix. Edinburgh: Waugh \& Innes.

Hermann Pálsson 1962. Sagnaskemmtun Íslendinga. Reykjavík: Mál og menning.

Hjálmar frá Hofi 1950. Kvöldskin: Ljóð. Reykjavík: Helgafell.

Íslendinga sögur (2 vols.). Jón Torfason, Sverrir Tómasson and Örnólfur Thorsson (eds.) 1985. Reykjavík: Svart á hvítu.

Íslensk Pjóðmenning VI: Munnmenntir og bókmenning 1989. Jóhannsson, Frosti F. (ed.). Reykjavík: Bókaútgáfan pjódsaga.

Jón Karl Helgason 1998. Hetjan og höfundurinn. Reykjavík: Heimskringla.

Jón Karl Helgason 1999. The Rewriting of Njáls Saga: Translation, Ideology and Icelandic Sagas. Clevedon: Multilingual Matters Ltd. Jón Karl Helgason 2001. Höfundar Njálu, Reykjavík:Heimskringla. Jónas Kristjánsson 1992. Eddas and Sagas: Iceland's Medieval Literature (trans. Peter Foote). Reykjavík: Hið íslenska bókmenntafélag. Lord, Albert 1960. The Singer of Tales. Boston: Harvard University Press.

Mitchell, Stephen A. 1985. The Sagaman and Oral Literature: The Icelandic Traditions of Hjörleifr inn kvensami and Geirmundr heljarskinn. Foley, John Miles (ed.). Comparative Research on Oral Traditions: A Memorial for Milman Parry. Columbus, Ohio: Slavika Publishers, 1987.

Monk, Thelonious 1954. Blue Monk. arranged by Steve Hill. London 1993: Wise Publications.

Ong, Walter 1982. Orality and Literacy. New York \& London: Routledge.

Perkins, Richard 1989. Objects and Oral Tradition in Medieval Iceland. Úr Dölum til Dala: Guðbrandur Vigfússon Centenary Essays. McTurk, Rory \& Wawn, Andrew. Leeds: Leeds Texts and Monographs.

Quinn, Judy 2000. From Orality to Literacy in Medieval Iceland. Old Icelandic Literature and Society. Ross, Margaret Clunies. Cambridge: Cambridge University Press.

Scholes, Robert \& Kellogg, Robert 1966. The Nature of Narrative. New York: Oxford University Press.

Schumann, Robert 1839. Humoreske. New York: Edwin F. Kalmus.

Scruton, Roger 1997. The Aesthetics of Music. Oxford: Oxford University Press. 